\title{
IDENTIFICATION OF SOME GLOBAL VOLCANIC HORIZONS BY MAJOR ELEMENT ANALYSIS OF FINE ASH IN ANTARCTIC ICE
}

\author{
by
}

Julie M. Palais

(Glacier Research Group/EOS, University of New Hampshire, Durham, NH 03824, U.S.A.)

and

Severine Kirchner and Robert J. Delmas

(Laboratoire de Glaciologie et Géophysique de l'Environnement, BP 96, 38402 St. Martin-d'Héres, France)

Acid fallout from volcanic eruptions is well documented in the Greenland and Antarctic ice sheets (Hammer and others, 1980; Hammer, 1984; Legrand and Delmas, 1987). However, to date, no volcanic ash (tephra) layers have been positively identified in association with any of the high electrical conductivity layers that mark the volcanic acid deposition. In this paper we report the results of a study of the chemical composition of insoluble microparticles filtered from five intervals of a core from the South Pole. These five intervals were identified by Kirchner (1988) as being due to volcanic fallout, on the basis of electrical conductivity and sulfuric acid measurements.

The major element composition of tiny $(<5 \mu \mathrm{m})$ glass shards found in these layers was determined and compared with analyses of volcanic ash from known eruptions or from volcanic sources suspected of having produced the fallout. Glass shards from volcanic eruptions of both local (Antarctic and sub-Antarctic) and of global (Indonesian/South American) importance have been identified in this study.

\section{INTRODUCTION}

Most ice core studies to date have used the chemical composition of the ice (excess sulfate, chloride, fluoride, acidity and electrical conductivity) as indicators of volcanic horizons (Hammer, 1977; Herron, 1982; Hammer, 1984; Legrand and Delmas, 1987; Langway and others, 1988). Work by Legrand and Delmas (1987) and Clausen and Hammer (1988) has suggested that a number of well-known volcanic eruptions have been recorded in the Antarctic and Greenland ice sheets, respectively, in the form of layers of elevated sulfuric acid (and in some cases hydrochloric and hydrofluoric acids).

Except for the particles from the 1982 El Chichon eruption identified by De Angelis and others (1985) in surface snow collected in Greenland in 1984, no large eruptions of global significance (e.g. Tambora 1815, Krakatau 1883) are known to have produced tephra layers (visible or otherwise) in either the Antarctic or Greenland ice sheets. Except in the case of local eruptions, which are recorded by visible ash bands (Gow and Williamson, 1971, Palais and others, 1987; 1988), volcanic eruptions have been identified, to date, purely on the basis of ice chemistry and the coincidence in time of the event and the peak in sulfuric acid or conductivity in the ice cores (Legrand and Delmas, 1987; Langway and others, 1988; Clausen and Hammer, 1988). This method is valid only for the historical time period.

\begin{tabular}{|c|c|c|c|}
\hline Sample & Depth (m) & Age (A.D.)* & Source/Notes \\
\hline PS1816 & $26.4-27.1$ & $1816-21$ & Tambora? \\
\hline PS1809 & $27.50-27.99$ & $1809-13$ & Local? \\
\hline PS1593 & $52.71-53.51$ & $1593-1600$ & $\begin{array}{r}\text { Huaynaputina } \\
1600 \text { A.D.? }\end{array}$ \\
\hline PS1589 & $53.51-54.36$ & $1589-93$ & $\begin{array}{l}\text { Ruiz } \\
\qquad 1595 \text { A.D.? }\end{array}$ \\
\hline S1259 & $87.50-88.04$ & $1258-64$ & $?$ \\
\hline
\end{tabular}

* Probable error \pm 5 years in upper layers and \pm 10 years in deeper layers.

\section{METHODS}

A study of a $130 \mathrm{~m}$ firn core from the South Pole by Kirchner and Delmas (1988) produced a 1000 year glaciochemical record, from which a number of horizons were identified that were thought to be due to volcanic eruptions. Kirchner (1988) discusses the methods which were used for dating this core and details of the glaciochemical analyses. A number of these layers were studied in order to try to identify glass shards from the volcanic eruptions thought to have produced the sulfuric acid peaks measured in the ice layers. In this paper we focus on five of these layers (Table I). Bulk melt-water samples $(\sim 50-100 \mathrm{ml})$ from these horizons were filtered and the insoluble particles on the filters were examined and analyzed by scanning electron microscope (SEM) and energy-dispersive $\mathrm{x}$-ray analysis (EDAX). The accuracy and precision of the analyses were determined by repeated measurements of synthetic and natural glass standards of known composition. The results of these analyses are shown in Table II.

\section{RESULTS}

Table III lists the major element composition of glass shards that were analyzed in some of the South Pole samples and corresponding analyses of possible sources or correlative tephra layers in other ice cores. Glass shards believed to be from the 1815 eruption of Tambora volcano were identified in an interval (1816-21 A.D.) of elevated sulfuric acid in the South Pole core (Table III, column 1). 
TABLE II. COMPARISON OF EDAX ANALYSES ${ }^{\mathrm{a}}$ OF SYNTHETIC AND NATURAL GLASS SHARDS WITH ACCEPTED VALUES

\begin{tabular}{|c|c|c|c|c|}
\hline & 1 & 2 & 3 & 4 \\
\hline Sample & $\operatorname{VSN}^{\mathrm{b}}$ & VSN & Ruiz 1985 & Ruiz 1985 \\
\hline $\mathrm{n}$ & 20 & - & 10 & \\
\hline Reference & this work & Accepted value & this work ${ }^{c}$ & Accepted value ${ }^{\mathrm{d}}$ \\
\hline $\mathrm{SiO}_{2}$ & $58.65(0.64)^{\mathrm{e}}$ & 57.01 & $66.87(0.90)$ & 65.36 \\
\hline $\mathrm{TiO}_{2}$ & $1.23(0.10)$ & 1.11 & $0.92(0.07)$ & 0.77 \\
\hline $\mathrm{Al}_{2} \mathrm{O}_{3}$ & $13.68(0.32)$ & 13.79 & $16.07(0.29)$ & 16.01 \\
\hline $\mathrm{FeO}^{*}$ & $3.99(0.31)$ & 4.25 & $3.86(0.31)$ & 3.98 \\
\hline $\mathrm{MnO}$ & 0.12 & 0.10 & 0.12 & n.a. \\
\hline $\mathrm{MgO}$ & $4.28(0.16)$ & 4.63 & $1.45(0.20)$ & 1.51 \\
\hline $\mathrm{CaO}$ & $4.81(0.23)$ & 4.67 & $3.59(0.41)$ & 3.81 \\
\hline $\mathrm{Na}_{2} \mathrm{O}$ & $4.59(0.41)$ & 6.11 & $3.00(0.53)$ & 4.12 \\
\hline $\mathrm{K}_{2} \mathrm{O}$ & $8.25(0.38)$ & 8.33 & $3.52(0.26)$ & 3.47 \\
\hline $\mathrm{P}_{2} \mathrm{O}_{5}$ & 0 & n.a. & $0.12(0.07)$ & 0.3 \\
\hline $\mathrm{SO}_{3}$ & $0.35(0.07)$ & n.a. & $0.39(0.09)$ & n.a. \\
\hline $\mathrm{Cl}$ & $0.06(0.05)$ & n.a. & $0.10(0.06)$ & n.a. \\
\hline \multicolumn{5}{|l|}{ Key: } \\
\hline \multicolumn{5}{|c|}{ n.a. $=$ not analyzed } \\
\hline \multicolumn{5}{|c|}{$\begin{array}{l}\mathrm{b}_{\text {synthetic glass standard (F. Guichard, CFR/CNRS, Gif-sur-Yvette, personal communication). }} \\
\text { c }_{\text {samples from } 1985 \text { eruptive activity collected in firn core (P. Laj, LGGE, personal communication). }}\end{array}$} \\
\hline
\end{tabular}

Microprobe analyses of matrix glass (Sigurdsson and Carey, in press), from the plinian fall deposit of the 1815 Tambora eruption compare very well and are also shown in Table III (column 2).

Glass shards from an interval of elevated sulfuric acid in the South Pole core, tentatively dated at about 1809-13, were analyzed and are shown in Table III (column 3). Legrand and Delmas (1987) described a double signal of elevated sulfuric acid ("the doublet") in ice cores from numerous sites in Antarctica. The original interpretation of this doublet was that the upper peak was due to the 1822 Galunggung eruption, whereas the lower one was due to the 1815 eruption of Tambora, but this was not positively demonstrated.

It is interesting to note that our analyses of shards in the 1809 layer are similar to those of Fehrenbach (1984) and De Angelis and others (1985) which were from a layer from the Dome $\mathrm{C}$ ice core, provisionally dated at 1815 , but now believed (because of the re-dating of the doublet) to be from an eruption in 1809 (Table III, column 4). In the light of this re-dating it is understandable that Fehrenbach (1984) and De Angelis and others (1985) were not able to identify particles from the Tambora eruption in their sample from Dome $C$, since they were looking in the wrong layer.

Analyses of glass shards in a layer with a sulfuric acid peak, dated at about 1593-1600 A.D. (Kirchner, 1988), are given in column 5. (Considering the potential errors in dating these samples, it is conceivably in error by no more than five to ten years (Kirchner, 1988).) If this age is too old by five to seven years, this event could be associated with the eruption of Huaynaputina (1600 A.D., Volcanic Explosivity Index $(\mathrm{VEI})=4)$. Glass shards from the 1600 A.D. eruption were previously found in an ice core from the Quelccaya ice cap, Peru (Thompson and others, 1984). A large acid signal is recorded in Greenland at this time (Hammer and others, 1980) but was not positively identified by these authors. A tephra sample (column 6) was obtained from the 1600 A.D. Huaynaputina eruption and analyzed at the same time as the particles in the South Pole core. Except for the slightly higher $\mathrm{SiO}_{2}$ in the tephra sample known to be from Huaynaputina (compared with those in the South Pole core), the identification of this horizon as being associated with the Huaynaputina eruption seems very likely.

Another sulfuric acid peak in the South Pole core, dated at about 1589 A.D., was found to have glass shards in it with a composition listed in Table III (column 7). Comparison with the analyses of Ruiz glass in columns 3 and 4 of Table II suggests that this layer might correspond to the 1595 A.D. eruption of Ruiz volcano, Colombia $(V E I=4)$. In that case, the age dating of this layer would also be in error by about seven years, but the distance between the two signals of this doublet (Huaynaputina-Ruiz) is essentially correct. 
TABLE III. MAJOR ELEMENT ANALYSES (wt\%) OF GLASS SHARDS IN SELECTED SOUTH POLE SAMPLES AND CORRESPONDING ANALYSES OF POSSIBLE SOURCES OR CORRELATIVE TEPHRA LAYERS IN OTHER ICE CORES

\begin{tabular}{|c|c|c|c|c|c|c|c|c|}
\hline Sample & 1 & 2 & 3 & 4 & 5 & 6 & 7 & 8 \\
\hline Age (A.D.) & $1816-21$ & 1815 & $1809-13$ & $1809-13$ & $1593-1600$ & 1600 & $1589-93$ & 1259 \\
\hline$(n, p)$ & $(16,5)$ & $(93, ?)$ & $(8,6)$ & $(13, ?)$ & $(18,16)$ & 7,7 & 12,7 & 24,8 \\
\hline Reference & this work & see below & this work & see below & this work & this work & this work & this work \\
\hline $\mathrm{SiO}_{2}$ & $57.83(1.42)$ & $57.63(0.97)$ & $59.74(1.40)$ & $59.45(1.63)$ & $72.92(2.04)$ & $75.76(0.53)$ & $66.70(0.87)$ & $67.28(0.91)$ \\
\hline $\mathrm{TiO}_{2}$ & $0.72(0.15)$ & $0.53(0.07$ & $0.83(0.16)$ & $0.67(0.24)$ & $0.34(0.20)$ & $0.27(0.06)$ & $0.93(0.12)$ & $0.55(0.13)$ \\
\hline $\mathrm{Al}_{2} \mathrm{O}_{3}$ & $18.53(0.74)$ & $19.62(0.36)$ & $15.66(1.75)$ & $16.43(0.51)$ & $13.98(0.91)$ & $13.85(0.15)$ & $15.72(0.76)$ & $15.64(0.22)$ \\
\hline $\mathrm{FeO}^{*}$ & $5.53(0.84)$ & $4.47(0.32)$ & $7.84(1.84)$ & $9.00(0.72)$ & $1.37(0.28)$ & $1.10(0.14)$ & $3.73(0.56)$ & $3.32(0.34)$ \\
\hline $\mathrm{MnO}$ & $0.28(0.21)$ & $0.16(0.11)$ & $0.16(0.07)$ & n.a. & $0.11(0.18)$ & $0.05(0.06)$ & $0.08(0.08)$ & $0.14(0.10)$ \\
\hline $\mathrm{MgO}$ & $1.48(0.36)$ & $1.29(0.13)$ & $2.33(0.92)$ & $2.83(0.73)$ & $0.44(0.20)$ & $0.27(0.14)$ & $1.51 \quad(0.35)$ & $0.82(0.18)$ \\
\hline $\mathrm{CaO}$ & $3.19(0.67)$ & $3.12(0.30)$ & $5.40(0.91)$ & $5.44(0.82)$ & $1.41(0.35)$ & $1.22(0.07)$ & $3.36(0.58)$ & $2.31(0.21)$ \\
\hline $\mathrm{Na}_{2} \mathrm{O}$ & $5.61(0.47)$ & $6.49(1.05)$ & $4.22(0.74)$ & $4.14(0.52)$ & $4.12(0.73)$ & $3.43(0.24)$ & $3.35(1.31)$ & $5.01(0.62)$ \\
\hline $\mathrm{K}_{2} \mathrm{O}$ & $6.02(0.54)$ & $6.36(0.33)$ & $3.08(1.37)$ & $2.05(0.40)$ & $3.76(0.28)$ & $3.89(0.15)$ & $3.37(0.35)$ & $4.19(0.22)$ \\
\hline $\mathrm{P}_{2} \mathrm{O}_{5}$ & $0.09(0.11)$ & $0.10(0.14)$ & $0.06(0.11)$ & n.a. & $0.02(0.05)$ & 0 & $0.13(0.25)$ & $0.03(0.05)$ \\
\hline $\mathrm{SO}_{3}$ & $0.34(0.13)$ & n.a. & $0.28(0.13)$ & n.a. & $0.99(0.52)$ & $0.15(0.06)$ & 0.87 (1.94) & $0.28(0.12)$ \\
\hline $\mathrm{Cl}$ & $0.47(0.12)$ & n.a. & $0.47(0.21)$ & n.a. & $0.55(0.18)$ & $0.12(0.05)$ & $0.34(0.05)$ & $0.49(0.10)$ \\
\hline
\end{tabular}

$$
\mathrm{n}=\text { number of analyses } \quad \mathrm{n} . \mathrm{a} .=\text { not analyzed } \quad \mathrm{p}=\text { number of particles }
$$

1. Tambora (?) glass, $1-3 \mu \mathrm{m}$ particles in sample PS 1816; compare with 2 .

1. Tambora (?) glass, $1-3 \mu \mathrm{m}$ particles in sample PS 1816; compare with 2 . and Carey (in press).

3. Dominant glass in samples PS1809; compare with 4.

4. Dominant glass from layer in the Dome C core originally dated 1815 but later interpreted to be from 1809; analyzed on same SEM/EDAX as this work (Fehrenbach (1984), De Angelis and others (1985)). Unknown source, possibly local; may be linked to a little known eruption of Cosiguina volcano in 1809 (Caldcleugh, 1836) compare with 3.

5. Dominant glass in sample PS1593, compare with 6. Probable fallout from Huaynaputina 1600 A.D. eruption (VEI $=4$ ).

6. Analysis of polished section of pumices from $10 \mathrm{~cm}$ thick ash layer $28 \mathrm{~km}$ from $\mathrm{crater}$ of Huaynaputina at altitude of $3070 \mathrm{~m}$. Sample provided by N. Vatin-Perrignon; compare with 5 .

7. Dominant glass in sample PS1589; compare with $3 / 4$ Table II. Probable fallout from Ruiz 1595 A.D. $(\mathrm{VEI}=4)$.

8. Dominant glass in sample from PS1259. Layer associated with strong sulfuric acid signal. Also seen in other parts of Antarctica and Greenland (Langway and others, 1988).

Finally, a strong sulfuric acid signal, thought to correspond to the 1259 A.D. volcanic-acid signal described by Langway and others (1988) in other Antarctic and Greenland cores, was identified in the South Pole core at about $87.5 \mathrm{~m}$ (Kirchner, 1988). Insoluble particles were extracted from a sample covering the period from about $1258-64$ A.D. and the analyses are given in column 8 . Although the exact volcano responsible for this eruption is unknown, it is thought to be located somewhere in the equatorial regions (Langway and others, 1988). Two possibilities include volcanoes of the Indonesian arc and volcanoes of central America and northern South America (e.g. Colombia, Ecuador). The precise identification of the volcano responsible for this event will require further analyses, including trace elements, as well as collaboration with volcanologists who are familiar with the volcanic histories of the potential source regions.

\section{DISCUSSION}

The identification of the sources of volcanic ash layers (both those with dispersed and with discrete ash) in a variety of media (marine sediment cores, ice cores, land-based deposits) is commonly made on the basis of the major element composition of glass shards in the layers (Smith and Westgate, 1969; Kennett, 1981; Palais and others, 1987).
Because the filter samples which were examined for this study were prepared from bulk melt-water samples which integrated from five to seven years of accumulation, a large variety of particle types was found in all samples. Most of the large $(>10 \mu \mathrm{m})$ particles can be explained by local (Antarctic/sub-Antarctic) sources whereas the smaller $(<10 \mu \mathrm{m})$ particles could have both local and distant sources. If the composition of the fine ash particles is not compatible with a local source, then a more distant source is suggested.

Most of the layers discussed here contained at least some fine ash that, because of its composition, was most likely transported from distant source regions. This fine ash was probably carried through the stratosphere along with the $\mathrm{SO}_{2}$ which caused the sulfuric acid deposition in the ice. $\mathrm{No}^{2}$ large particles of the same composition were found in these layers, suggesting that the coarse ash from these eruptions remained in the troposphere, did not travel very far and had only a local impact.

The particles discussed in this study were identified primarily because we knew where to look and what to look for. There is no doubt that it is more difficult to identify an unknown eruption (e.g. 1259 A.D.) for which there is little or no historical record. In order to do this, sampling must be finer and must be extended to other ice core locations. Analysis of tephra samples from suggested source areas should be analyzed at the same time as the ice core 


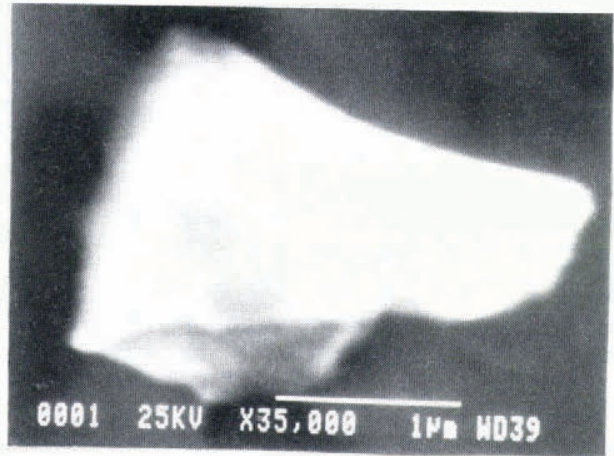

a

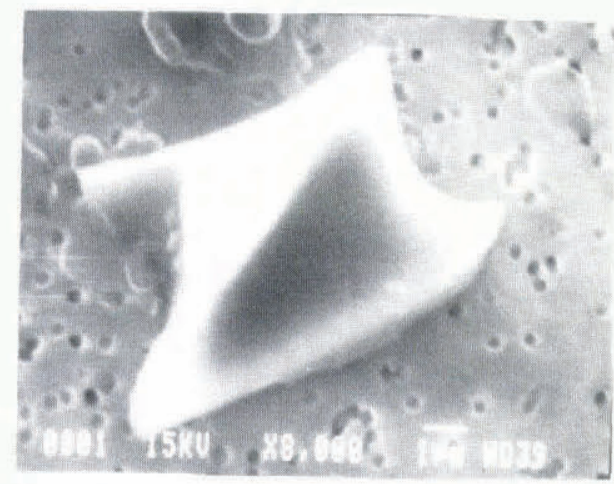

C

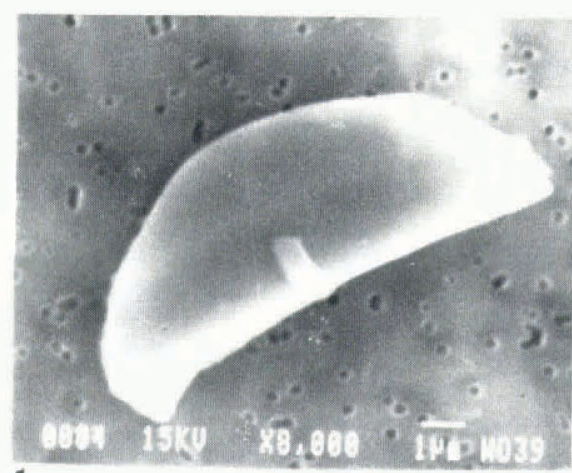

b

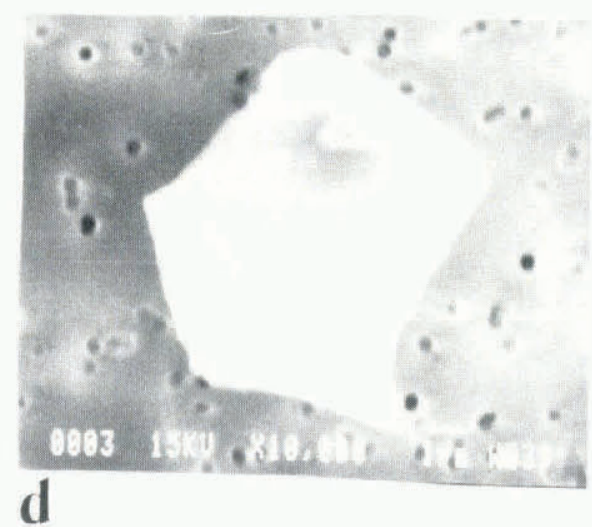

Fig. 1. Scanning electron micrographs of particles in the South Pole core thought to be from volcanic eruptions listed in Table I (a) Tambora 1815 A.D. (b) Huaynaputina 1600 A.D. (c) Ruiz 1595 A.D. (d)
Unknown 1259 A.D.

tephra in order to compare glass compositions for purposes of correlation.

\section{SUMMARY}

It is evident from the above discussion that the extraction and analysis of volcanic particles from layers of elevated acidity, as well as visible tephra layers in ice cores, can provide important information for dating and correlation purposes. In the case of the South Pole core studied by Kirchner (1988), the identification of fine ash particles in the volcanic acid horizons provides strong support that these acid peaks are due to fallout from known volcanic eruptions and thus allow a refinement of the dating proposed by Kirchner (1988) based on independent information. Volcanic particles can be used not only to date and cross-correlate events between cores but also to help document the eruptive history of volcanic regions. Since many of the most explosive volcanic eruptions in the past are known to have occurred in the equatorial regions (e.g. Toba-75 ka, Tambora, 1815 A.D., Krakatau, 1883 A.D.), it is likely that tephra from these eruptions has been deposited on both the Antarctic and Greenland ice sheets. The potential of using tephra layers for interhemispheric ice core correlations seems very promising.

\section{ACKNOWLEDGEMENTS}

Analyses were performed at the Centre des Faibles Radioactivitiés, C.N.R.S./C.E.A., Gif-sur-Yvette, France. J. Palais thanks L. Labeyrie, M. Paterne and C.C. Jehanno for their assistance with this work. Funding for this study was provided by a French government fellowship (Chateaubriand Fellowship) to J.M. Palais.

\section{REFERENCES}

Caldcleugh, A. 1836. Some account of the volcanic eruption of Coseguina in the Bay of Fonseca, commonly called the Bay of Conchagua on the western coast of Central America. Phil. Trans. R. Soc. Lond. 1, 27-30.

Clausen, H.B. and C.U. Hammer. 1988. The Laki and Tambora eruptions as revealed in Greenland ice cores from 11 locations. Ann. Glaciol., 10, 16-22.

De Angelis, M., L. Fehrenbach, C. Jehanno, and M. Maurette. 1985. Micrometre-sized volcanic glasses in polar ices and snows. Nature, 317(6032), 52-54.

Fehrenbach, L. 1984. Analytical microscopy of volcanic glass microparticle fallout in polar ice cores (Microscopie analytique de micro-particules de verre volcanique piégees dans les glaces polaires). Bulletin PIRPSEV-CNRS 94.

Gow, A.J. and T. Williamson. 1971. Volcanic ash in the Antarctic ice sheet and its possible climatic implications. Earth Planet. Sci. Lett., 13(1), 210-218.

Hammer, C.U. 1977. Past volcanism revealed by Greenland ice sheet impurities. Nature, 270(5637), 482-486.

Hammer, C.U. 1984. Traces of Icelandic eruptions in the Greenland ice sheet. Jökull, 34, 51-65.

Hammer, C.U., H.B. Clausen, and W. Dansgaard. 1980. Greenland ice sheet evidence of post-glacial volcanism and its climatic impact. Nature, 288(5788), 230-235.

Herron, M.M. 1982. Impurity sources of $\mathrm{F}^{-}, \mathrm{Cl}^{-}, \mathrm{NO}_{3}{ }^{-}$, and $\mathrm{SO}_{4}{ }^{2-}$ in Greenland and Antarctic precipitation. $J$. Geophys. Res., 87(C4), 3052-3060.

Kennett, J.P. 1981. Marine tephrochronology. In Emiliani, C., ed. The sea. Vol. 7. The oceanic lithosphere. New York, John Wiley, 1373-1436.

Kirchner, S. Unpublished. Chimie de la neige $(\mathrm{Na}, \mathrm{Cl}$, $\mathrm{NO}_{3}, \mathrm{SO}_{4}$ ) à la Station Pole Sud. (Ph.D. thesis, Université Scientifique et Médicale de Grenoble, 1988.) 
Kirchner, S. and R.J. Delmas. 1988. A 1000 year glaciochemical study at the South Pole. Ann. Glaciol., 10, 80-84.

Langway, C.C., jr, H.B. Clausen, and C.U. Hammer. 1988. An inter-hemispheric volcanic time-marker in ice cores from Greenland and Antarctica. Ann. Glaciol., 10, 102-108.

Legrand, M. and R.J. Delmas. 1987. A 220-year continuous record of volcanic $\mathrm{H}_{2} \mathrm{SO}_{4}$ in the Antarctic ice sheet. Nature, 327(6124), 671-676.

Palais, J.M., P.R. Kyle, E. Mosley-Thompson, and E. Thomas. 1987. Correlation of a 3,200 year old tephra in ice cores from Vostok and South Pole stations, Antarctica. Geophys. Res. Lett., 14(8), 804-807.

Palais, J.M., P.R. Kyle, W.C. McIntosh, and D. Seward. 1988. Magmatic and phreatomagmatic volcanic activity at Mt. Takahe, West Antarctica, based on tephra layers in the Byrd ice core and field observations at Mt. Takahe. J. Volcanol. Geotherm. Res., 35(4), 295-317.

Sigurdsson, H. and S. Carey. In press. The 1815 eruption of Tambora: generation of co-ignimbrite ash during entrance of pyroclastic flows in the ocean. Bull. Volcanol.

Smith, D.G.W. and J.A. Westgate. 1969. Electron probe technique for characterising pyroclastic deposits. Earth Planet. Sci. Lett., 5, 313-319.

Thompson, L.G., E. Mosley-Thompson, W. Dansgaard, and P.M. Grootes. 1986. The Little Ice Age as recorded in the stratigraphy of the tropical Quelccaya ice cap. Science, 234(4774), 361-364.

Williams, S.N., and 6 others. 1986. Eruption of the Nevado del Ruiz volcano, Columbia, on 13 November 1985: gas flux and fluid geochemistry. Science, 233, 964-967. 